\title{
Gender segregation in farm labour, its roles and dynamic during Covid pandemic: case study from West Nusa Tenggara, Indonesia
}

\author{
Nurul Hilmiati*, Ulyatu Fitrotin, Irma Mardian, Putu Adnyana, Awaludin Hipi, Johanes \\ Geli Bulu
}

Assessment Institute for Agricultural Technology West Nusa Tenggara, Mataram, Indonesia

\begin{abstract}
Farm labour plays significant roles in crops production. This paper aims to describe gender segregation in crops farming, its roles and dynamic during Covid pandemic in West Nusa Tenggara. A survey was conducted in three districts, East Lombok, Sumbawa and Bima, involving 102 farmers. Qualitative and quantitative data were collected using interview method which then analysed descriptively. The results showed that most respondents employed woman labours for planting and mixed labour for harvesting amid the land ownership discrepancy and agroecology conditions. Women were considered to be more skilful and diligent than men. Nevertheless, they received lower pay by $50-100 \%$ on daily basis. Covid pandemic situation has posed varying effects on labour prices, work availability and movement. Labour prices generally has increased due to increasing prices of basic needs, yet work availability decreased as land owners tried to reduce cost because of rocketing fertiliser prices. Pandemic situation did not affect labour movement was in East Lombok and Bima since majority farmers used local labour. While in Sumbawa, as many farmers relied on migrant labour from Lombok and Bima for harvesting, the 2020 has affected harvest quality and subsequently selling prices due to late harvest since labours were not allowed to travel.
\end{abstract}

\section{Introduction}

Agricultural farming across Indonesia, including in West Nusa Tenggara (WNT) Province, is inseparable from farm labour. Farm labour is involved in every stage of farming activity making it as one of the potential job opportunities outside urban areas [1,2]. At the same time, gender has played historically important in shaping the labour in agricultural production [3]. Gender is usually associated with productive and reproductive roles as well as responsibility distribution between men and women in a society, as a social process to construct reality depend on socio-cultural context in certain areas $[4,5,6]$.

A number of papers have explored farm labour and gender dimension in Indonesia $[7,8]$. However, only few papers have addressed the farm work segmentation related to gender for crops farming under the context of WNT. This paper aims to describe gender segregation in

\footnotetext{
* Corresponding author : hilmiati@yahoo.com
} 
rice and maize farm labour, its roles and dynamic during Covid pandemic in West Nusa Tenggara.

\section{Methodology}

This study was conducted using survey methodology [9] in three districts of West Nusa Tenggara Province namely East Lombok, Sumbawa and Bima by involving 103 farmers. East Lombok district is located in Lombok Island while Sumbawa and Bima District are located in Sumbawa Island. Farmers were selected purposively based on farming system. Respondents in this study implemented integrated crops-livestock system where rice and maize as the main crop and cattle as the main livestock. Quantitative and qualitative data were collected and then tabulated for descriptive analysis.

\section{Results and discussion}

\subsection{Agroecological conditions and cropping pattern of WNT}

West Nusa Tenggara (WNT) Province consist of two main islands, Lombok and Sumbawa islands. WNT that consists of 2 million ha of land, around $69 \%$ is dominated by dry climate and almost $75 \%$ of hilly topography $[10,11,12]$. Generally, Sumbawa is drier than Lombok Island dominated by rain fed area. A study [13] reported that almost all WNT region fall under dry-climate zone and only $5 \%$ land is in wet-climate conditions found in Central Lombok, West Lombok and East Lombok Districts. On the other word, Lombok is more fertile than Sumbawa Island [14]. Given these conditions, farmers adjust this climatic condition by planting dry tolerant and short harvest period commodities such as maize, mung bean and ground peanut. These different climatic conditions are greatly related to cropping pattern across the three districts as shown in Table 1.

Rice is the most common crop in all districts during rainy season (first planting round) across the three districts where most farmers store some portion of the harvested rice for family consumption This can be understood as rice is the staple food majority of Indonesian people including in WNT [15]. Hence, storing rice will create sense of food security for the farmer household. In East Lombok which was dominated by irrigated areas, farmers were able to have three planting rounds in a year with some variation of the crops in the second and third planting round including maize, chilli and tobacco. Meanwhile, some irrigated part of Sumbawa Island was able to plant two or even three rounds of rice like in, Moyo Hilir, Bolo, Madapangga and Monta. However, although the irrigation system enables farmers to have three planting rounds, farmers in Moyo Hilir prefer to leave the land into fallow to allow cattle graze the crop residue. Meanwhile, the up land areas both in Sumbawa and Bima were dominated by maize commodity. The different was that farmers in upland Sumbawa District plant maize in relay system with mung bean, soy bean or ground nut. Residue of these legume crops ware conserved as cattle feed for the next dry season. These findings are consistent with previous study by [16] that upland farmers in Sumbawa tend to plant dry tolerant and short harvesting period crops such as maize and pulses like mung bean and ground nut to adjust narrow window of rain season period. Pulses crops are planted in relay system with maize to optimize soil moisture towards the end of rain season [17]. In fact, yield from pulse crops generates significant income for upland farmer as closely similar important than of from maize.

The different cropping pattern across three districts reflects farmers strategy under the integrated crop-cattle farming system. In all irrigated study areas of East Lombok, farmers plant three times round as the cattle are kept under an intensive system while farmers in 
similar farm land type in Sumbawa prefer to plant two rounds as the third round is left fallow to allow cattle grazing the rice straw. Cropping pattern of irrigated land in East Lombok was quite similar to those in Bima as majority farmers run fattening enterprise by feeding cattle intensively in the pen. This integrated crop-cattle system has long been identified as a livelihood strategy of small holder farmers in Nusa Tenggara region where cattle play significant roles as family economic buffer during harvest failure, for large expenditure and sudden capital need [18]. This explains reasons farmers in Sumbawa leave the farm land in fallow at least for one planting round to allow cattle graze the crop residue.

Table 1. Cropping pattern in East Lombok, Sumbawa and Bima District

\begin{tabular}{|c|c|c|c|c|}
\hline District & Sub-district & \multicolumn{3}{|c|}{ Land Type } \\
\cline { 3 - 5 } & Terara & $\begin{array}{c}\text { Rice - maize - vegetables } \\
\text { Rice - tobacco }\end{array}$ & NA & Up land \\
\hline $\begin{array}{c}\text { East } \\
\text { Lombok }\end{array}$ & Keruak & Rice - maize - maize & NA & NA \\
\hline & Sikur & Rice - maize - maize & NA & NA \\
\hline & Moyo Hilir & Rice - rice - fallow & NA & NA \\
\hline Sumbawa & Moyo Utara & NA & Rice - fallow & NA \\
\hline & Plampang & NA & $\begin{array}{l}\text { Maize - mung } \\
\text { bean/ ground } \\
\text { peanut - fallow }\end{array}$ \\
\hline & Labangka & NA & NA & $\begin{array}{l}\text { Maize - mung } \\
\text { bean/ ground } \\
\text { peanut - fallow }\end{array}$ \\
\hline & Bolo & Rice - rice - rice/soy bean & NA & NA \\
\hline Bima & Madapangga & Rice - rice - rice & NA & NA \\
\hline & Monta & Rice - rice - rice & NA & Maize - fallow \\
\hline
\end{tabular}

Source: primary data

\subsection{Land tenure and farming system}

Majority of farmers in West Nusa Tenggara implement integrated crop-livestock system with rice and maize as the main crops commodity and cattle being one of the most important livestock to support family economy. Land tenure in West Nusa Tenggara varies between districts but generally larger in Sumbawa compared to Lombok Island. Average land tenure in East Lombok, Sumbawa and Bima based on the land type is shown in Table 2. Table 2 shows that farmers in Lombok had the least land tenure of 0,41 ha and 0,23 ha for irrigated and rain-fed farm land respectively. Meanwhile Sumbawa district holds the largest land tenure for all type of land accounted for 1,02 ha, 1,40 ha and 2,59 respectively for irrigated, rain-fed and up-land. This is reasonable as Sumbawa District holds more than a third of total WNT province area with resident density of 69 people $/ \mathrm{km} 2$, compared to 112 people/ $\mathrm{km} 2$ in Bima and 753 people/ $\mathrm{km} 2$ in East Lombok [19].

Table 2. Land tenure based on type in East Lombok, Sumbawa and Bima District

\begin{tabular}{|c|c|c|c|}
\hline \multirow{2}{*}{ District } & \multicolumn{3}{|c|}{ Average land tenure per type of land (Ha) } \\
\cline { 2 - 4 } & Irrigated farm land & Rain-fed farm land & Up-land \\
\hline East Lombok & 0,41 & 0,23 & NA \\
\hline Sumbawa & 1,02 & 1,40 & 2,59 \\
\hline Bima & 0,60 & 0,50 & 0,90 \\
\hline
\end{tabular}


An interesting finding in this study is the land tenure for irrigated land in East Lombok that accounted for 0.40 ha per household. This is in contrast with previous study by [20] who found smaller average land tenure for just 0.25 ha per household in Lombok. This can be possible due to different sampling location and target group of respondents. In the Puspadi's study, the respondents were mainly cattle farmers whom some of them may not have land. In fact, rearing cattle is one of their livelihood strategies to overcome landless condition as they can collect feed freely in the communal areas such as road side, river banks and rice bund. In the other word, cattle framing enables them to convert free feed into cash through cattle farming.

Different size of land tenure between East Lombok, Sumbawa and Bima shows correspondence to the integrated crop-cattle farming system in these three districts. Small land tenure in East Lombok has made cattle farmers to implement intensive cut-and-carry system. Improved forage such as elephant and king grass and tree legume like Sesbania are generally planted in the rice bund. Landless cattle farmers collect feed from communal land such as road and river side. This system is contrasting to the other two districts in Sumbawa Island with much larger land tenure. Meanwhile, in Sumbawa and Bima Districts cattle are managed in a rather extensive system for cow-calf production and in an extensive for cattle fattening. These findings were consistent with previous study [21]. For cow-calf production, cattle are kept in a pen during crop season (December to June/July). Pen were varying in form, some were only wooden fence without roof while others had roof in better construction. During this penning period, farmers offer water and feed, mostly in dried form, feed consisted of dried mung bean, ground peanut and rice straw from the last year harvest. After harvest season, cows, calves and young cattle are released from the pen to freely graze maize crop residue. Meanwhile, cattle for fattening stay in the pen all year round and fed by Leucaena.

\subsection{Gender preference in farm labour}

Most farming works in West Nusa Tenggara involve farm labour including land tillage, planting, weeding, harvesting and post-harvest. This is supported by a statistic stating higher labour force available in rural areas than in urban areas, accounted for $54,6 \%$, in which agricultural sector provides highest work opportunity [22]. At the same time, women's involvement in small holder farming has been documented in a number of studies [23,24,25, 26]. This study has found gender segregation in those different type of work. Planting work was the most gender segregated work especially for rice farming where woman labours dominate it across the three districts. Among reasons mentioned by respondents include women work more diligently, faster and better result than men. Some respondents even reported that man labours cannot do planting work. Even if they do, they are very slow in taking the rice seedlings from the bundle or putting maize seeds into planting holes. Hence, most farmers preferred using woman labours for planting. Few man labours are employed for carrying rice seed bundles or maize seed bags. However, payment for women labour was found contradicted to their important role for planting. They received less payment by up to $50 \%$ than the men counterpart for daily work. When women labour received Rp. $60.000-$ 70.000 , men labour would receive Rp. 100.000 for daily work. This is because men are considered working for the harder and muscle need jobs such as making planting lines and carrying rice bundles. This finding confirms a previous study by [27] that women involvement in agriculture is based on necessity not on the equity. Therefore, there is still inequality for women in agricultural labour payment despite their work preferred work in WNT.

Labour for farming work were paid in various form and rates depend on the work type, habit and consensus in the respective location. Planting work is usually paid by cash on daily basis either counted half day or full day as shown in Table 3 . There is a great variation of 
rates between sites. In general, the rates in Sumbawa and Bima were higher than those in East Lombok at similar working hours accounted by around $25 \%$. This was possibly related to resident population and labour availability as population in East Lombok is almost triple the population in Bima or Sumbawa Districts. Hence, more labour is likely available in East Lombok. Following the demand and supply principles, when the labour supply is high then the rates will be lower. Yet, Bolo village in Bima showed specialty as the labour rates were not influenced by supply and demand. The rates have been constant in the last four years at Rp. 70.000 / full day attributed to the village regulation. This kind of regulation was considered to be fair by farmers and as a win-win solution to avoid users or labour domination in determining labour work prices. There is another interesting planting scheme for maize that was found in Sumbawa called "besiru" or "siruan". It is a system of a group of farmers consist of 7-10 people to help each other without payment. Unfortunately, this helping each other system was not found in many places.

Table 3. Farm labour rates from rice planting in NTB

\begin{tabular}{|c|c|c|c|c|c|c|}
\hline Village & Sub-district & District & Daily rates & $\begin{array}{c}\text { Before } \\
\text { Covid }\end{array}$ & $\begin{array}{c}\text { Working } \\
\text { period }\end{array}$ & $\begin{array}{c}\text { Working } \\
\text { hour (hrs) }\end{array}$ \\
\hline Bolo & Madapangga & Bima & 70.000 & 70.000 & $07.00-16.00$ & 8 \\
\hline Nggembe & Bolo & Bima & 50.000 & 40.000 & $07.00-15.00$ & 7 \\
\hline Tangga & Monta & Bima & 50.000 & 40.000 & $08.00-12.00$ & 4 \\
\hline Dasan Baru & Wanasaba & Lotim & 35.000 & 30.000 & $08.00-12.00$ & 4 \\
\hline Jenggik & Terara & Lotim & 60.000 & 45.000 & $08.00-16.00$ & 7 \\
\hline Pijot & Keruak & Lotim & 25.000 & 20.000 & $07.00-11.000$ & 4 \\
\hline Ndut & Sikur & Lotim & 30.000 & 30.000 & $07.00-12.00$ & 5 \\
\hline Penyaring & Moyo Utara & Sumbawa & 70.000 & 70.000 & $07.00-16.00$ & 8 \\
\hline Berare & Moyo Hilir & Sumbawa & 70.000 & 70.000 & $07.00-16.00$ & 8 \\
\hline
\end{tabular}

While cash out labour payment was almost uniform for rice planting across the three districts, harvest payment for rice varied greatly. Majority were paid bay cash on daily basis but some others in Sumbawa and East Lombok were paid by husked rice. In Sumbawa it is called "singguh" either singguh 12 or singguh 14. Singguh 12 means 12 bags/ portion of the harvested rice goes for the owner and 2 bags go for the labour. In Lombok it is called Nyiwak (nine) or Nyembaluk (eight). Nyiwak means out of the nine bags of harvested rice, eight goes for the owner and one goes for the labour. Other payment system was found for maize harvest particularly in Plampang and Labangka sub-districts of Sumbawa. Labour was paid in a package form accounted for Rp. 2.500.000 / ha. The labour was also interesting coming from Lombok, Bima and as far as Sumba Island. This was possibly because these areas are transmigrant sites with labour shortage. Hence, farmers try to bind work responsibilities by putting it in a package form.

\subsection{Covid-19 pandemic and dynamics of farm labour}

Covid pandemic situation has impacted on farm labour in WNT at various level. The lock down period from March - June in 2020 coincided with harvest period of the first planting round of that year. Port closure and travel restriction had a great impact on labour availability. Sumbawa district was the worst impacted especially for maize farmers in Plampang and Labangka sub-district. Delayed harvest and improper post-harvest handling due to labour shortage had decreased quality leading to decreased prices. During harvesting Meanwhile, 
rice farmers overcame this situation by employing combine harvester provider, hence harvest loss could be reduced.

Although maize farmers in some part of Sumbawa experienced severe labour shortage during harvest period in first planting round of 2020, farmers in Bima, East Lombok and rice farmers in Sumbawa reported dissimilar conditions. In general, there was no significant difference in labour availability as they employed local labours from similar village or neighbouring villages. Majority of respondents from these areas reported that even during lock down period, people still went out inside the village and did normal farm activities. This result shows similarity with a previous study [16] that finding labour in the village area is generally easy. Similar findings was presented by [28] that there is no farmers behaviour change in working during Covid pandemic. Farmers consider that working in the field is safe as they are under the sun light with fresh air and in a distance with other farmers.

Labour rates showed slight changes before and during Covid pandemic in majority of the study sites. It has increased by around $20 \%$ in average and varied from $13 \%$ to $33 \%$. As an example, labour daily rate in Monta, Bima has increased from Rp. 40.000 to Rp. 50.000 for half day and in Wanasaba, East Lombok from Rp. 30.000 to Rp. 35.000. Labour for maize harvest in rain season 2021 has also increased from Rp. 2,5 million /ha into Rp. 3 million/ha. Respondents reported that farm labour requested increase rates because of increasing goods prices.

\subsection{Roles of farm labour for innovation up take: how can we go about it?}

Innovations and technology in crops farming plays significant roles in improving its productivity. However, innovations in various stage of crops farming are not implemented yet by farmers for various reasons. Given the situation that labour is an integral part of crop farming and gender segregation in labour itself, this study proposes two dimensions for innovation up take. The first is labour capacity building for innovation uptake. By and large, introduction of innovations often focuses to the farmers or owner of the land with very few attentions to labour that doing the work where innovations need to be implemented. Therefore, increasing labour skills and capacity in implementing the innovations will provide greater possibility for innovation uptake. One of the examples is planting rice in double spaced row. This innovation has been proven to improve productivity. Although the farmers (land owner) have been trained and got technical information and keen to implement it, often it cannot be implemented because the labours who work the planting cannot do it. This shows that capacity development and technology assistance need to be balanced between farmers and farm labour as they are intertwined each other.

The second dimension for innovation uptake is the gender segregation of farm labour. Women has shown significant roles in some important stage of the farming that such as planting. Yet, gender dimension if often overlooked during capacity development for innovation implementation. Women in rural areas tend to face difficulties than men in accessing services, including service for technical assistance [5]. Trainings often target mainly men as participant and conduct in less gender sensitive manner such as less attention to women preference on time, preferred trainer and training organisation itself. This is in line with a study [16] that women have not been involved much in improving access and control over agricultural development resources, including access to extension services. Given that women in this study have shown significant roles in farm work, gender aspect need to be more included in technical trainings of those works. Creating comfortable environment for training participants will provide greater possibility for the trainee to understand and internalize the training contents and subsequently implement them. 


\section{Conclusions}

Gender has been significant in shaping the crop farming in West Nusa Tenggara. Women labour plays key role for planting as they are more trusted and preferred due to the work results, and equally important and preferred with men colleague for other works such as weeding and harvesting. Despite user preference on women labour for certain type of farm work, there is payment discrepancy with men counterpart under similar working hours. Men labour are perceived to have harder work hence deserve to get higher payment. Meanwhile, farm labour movement and availability were impacted by Covid in Sumbawa during the lock down period but has returned to almost normal again in 2021. Similar impact was not found in Bima and East Lombok because farmers used labour from inside the village. Since farm labour has been inseparable with farm productivity and gender segregation involvement in it, there are two dimensions to improve farm productivity through innovation implementation. The first is labor involvement in capacity building activities for innovation up take; and the second is gender sensitive approach in capacity building activities.

\section{References}

1. I. W. Rusastra, M. Suryadi. Jurnal Litbang Pertanian. 23, 91 (2004)

2. I. Setiawan. Jurnal Geografi Gea. 6, 1 (2006)

3. A. Alesina, P. Giuliano, N. Nunn. The Quarterly Journal of Economics. 128, 469 (2013)

4. I. Abdullah. Humaniora. 15, 265 (2003)

5. FAO. Understanding and integrating gender issues into livestock projects and programmes. (FAO Rome, Italy, 2013)

6. Hafizianor, R. Muhayah, S. Zakiah. Journal Hutan Tropis. 3, 2 (2015)

7. M. Syarifudin. eJournal Sosiatri-Sosiologi. 4, 98 (2016)

8. H. Puspitawati, A.C.J. Putri, A. Titipani, M.N. Khasanah. Jur. Ilm. Kel. \& Kons. 2, 87 (2019)

9. R. M. Groves, F. J. Fowler, Jr, M.P. Couper, J. M. Lepkowski, E. Singer, R. Tourangeau. Surevy methodology. (Wiley, 2009)

10. Balitklimat. Atlas sumberdaya iklim agroklimat untuk pertanian (in bahasa) (Balai Penelitian Agroklimat dan Hidrologi, Bogor, (2003)

11. A. Mulyani, A. Pramudia, A. Sukarman, H. Hartomi, D. Allorerung. Laporan akhir identifikasi dan evaluasi kesesuaian lahan jarak pagar (Jatropha curcas 1.), (Indonesia Centre for Agricultural Land Resources Research and Development, Bogor, 2010)

12. D. Nursyamsi, M. T. Sutriadi, E. Suryani, S. Bachri, N. Prasodjo. Atlas peta kesesuaian lahan dan arahan pengembangan komoditas provinsi Nusa Tenggara bBrat dan Nusa Tenggara Timur. (Badan Penelitian dan Pengembangan Pertanian Indonesia, Jakarta, 2016)

13. A. Suryadi, A. Mulyani, L. Hadiawati, Suratman. Procedings of IOP Conf. Series: Earth and Environmental Science 648, (2021)

14. B. Winarso. Jurnal Penelitian Pertanian Terapan. 12, 103 (2012)

15. D. R. Panuju, K. Mizuno, B. H. Trisasongko. Journal of the Saudi Society of Agricultural Science. 12 (2013)

16. N. Hilmiati. Jurnal Sosial Ekonomi Pertanian SOCA. 13, 143 (2019) 
17. Sudarto, Y.G. Bulu, F. Zulhaidar. 2017. Proceedings of the Innovation for sub-optimal land to develop pulses and tuber crops in supporting food sovereignty. Pusat Penelitian dan Pengembangan Tanaman Pangan, Balitkabi, 25 Mei 2016, Malang, Indonesia (2017)

18. N. Hilmiati, B. Budiwiranto, E. van de Fliert. Rural Extension \& Innovation Systems Journal. 13, 12 (2017)

19. BPS NTB. https://ntb.bps.go.id/indicator/153/56/1/luas-daerah-nusa-tenggarabarat.html. Retrieve 19 July 2021 (2020)

20. K. Puspadi, Zaenuri, P. Sudrana, Dahlanuddin. Optimalisasi kelembagaan kandang kompleks untuk mengembangkan model industri pembibitan sapi Bali di Pulau Lombok. Paper presented at the Pengembangan sapi Bali berkelanjutan dalam sistem peternakan rakyat, Mataram (2009)

21. N. Hilmiati, Sutartha, T. Panjaitan. OIDA International Journal of Sustainable Development. 9, 1 (2016)

22. T. Budiprayitno, Asnirawati, D. Suhartini, D. Efendi, U. Azmi, H. Jauhari, Sabri, Sunari, I. N. Subagia, Indarti. Data statistik ketenaga kerjaan Provinsi NTB (Dinas Komunikasi Informatika dan Statistik Provinsi Nusa Tenggara Barat, 2019)

23. S. S Mugniesyah, F. Pamela. Gender analysis pathway dalam sektor pertanian (Bapenas \& CIDA, Jakarta, 2001)

24. E. Roosganda. Forum Penelitian Agro Ekonomi. 25, 2 (2007)

25. Y.I. Ogunlela, A. A. Mukhtar. Humanity \& Social Sciences Journal. 4, 1 (2009)

26. P. R. Endang, I. M. N. Tenaya, N. W. S. Astiti. Jurnal Manajemen Agribisnis. 2, 1 (2014)

27. K. Suradisastra. FAE. 16, 2 (1998)

28. N. S. Wisnujati, E. Noerhartati. International Journal of Entrepreneurship and Business Development. 3, 3 (2020) 